\title{
Growth of rice plants in an Acrustox fertilized with silicon and manganese
}

\author{
Adubação do arroz com silício e manganês em um Latossolo Vermelho
}

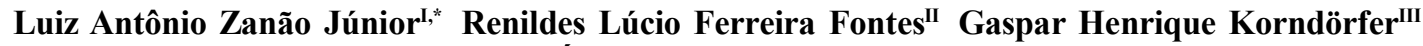 Vinícius Tavares de ÁvilaII Maristela Pereira Carvalho-ZanãoI}

\begin{abstract}
The objective of this research was to study the biomass production, plant architecture and Si and Mn uptake in rice plants cultivated in a Acrustox fertilized with silicon and manganese. The experiment was carried out in a greenhouse using a $2 \times 5$ factorial (0 and $1000 \mathrm{mg} \mathrm{dm}^{-3}$ Si $x$ 0, 4, 12, 16 and $20 \mathrm{mg} \mathrm{dm}^{-3} \mathrm{Mn}$ ) with four replications, in a randomized block design. The application of Si to the soil resulted in a smaller leaf insertion angle, a greater Si content in the leaves and roots and biomass production. Moreover, Si caused the decrease content of Mn in leaves and its increase in roots. With the rising dose of Mn, there was an increase in the content of this element in soil, roots and leaves, regardless of the Si application and reduction in biomass production of rice in the larger doses only when the Si was not added to the soil.
\end{abstract}

Key words: Oryza sativa L., silicate, Oxisol, plant nutrition.

\section{RESUMO}

O objetivo deste trabalho foi avaliar a produção de biomassa, a arquitetura da planta e os teores de Si e Mn em plantas de arroz cultivadas em amostras de um Latossolo Vermelho distrófico típico fertilizado com manganês e silício. $O$ experimento foi conduzido em casa de vegetação, em um fatorial 2x5 (0 ou 1000mg dm-3 Si x 0, 4, 12, 16 e $20 \mathrm{mg} \mathrm{dm}^{-3}$ $\mathrm{Mn})$, em quatro repetições, em blocos ao acaso. A adição do Si ao solo resultou em menor ângulo de inserção foliar e em maiores teores de Si nas folhas e raizes, como também em maior produção de biomassa. Além disso, houve diminuição nos teores foliares de Mn e aumento em seus teores radiculares. Com o aumento da dose de Mn, houve aumento nos teores deste elemento no solo, nas raizes e nas folhas, independentemente da aplicação do $\mathrm{Si}$, e redução na produção de biomassa do arroz nas maiores doses apenas quando o Si não foi adicionado ao solo.

Palavras-chave: Oryza sativa L., silicato, Latossolo, nutrição de plantas.

The availability of Mn increases in acid soils and may cause toxicity problems since high plant $\mathrm{Mn}$ concentrations may severely reduce plant production (EL-JAOUAL \& COX, 1998). Lime application, which reduces $\mathrm{Mn}$ availability by increasing the $\mathrm{pH}$ of the soil, may avoid the Mn toxicity (OLIVEIRAJÚNIOR. et al., 2000).

It has been reported that $\mathrm{Si}$ performs a very important role in plant tolerance to toxicity caused by $\mathrm{Mn}$, a fact observed in various species such as rice, bean, cowpea and cucumbers. It diminishes the transport of Mn from the roots to the shoots with strong connection of $\mathrm{Mn}$ to the cell wall; reducing its concentration in the symplast and the lipid peroxidation of the membrane (LIANG et al., 2007). These reported studies are related to experiments with plants growing in nutrient solution.

Related to the interaction Si x Mn, it has to be considered in the Brazilian Cerrado, a region where the predominant soil is the Oxisol class, which has low Si availability (RAIJ \& CAMARGO, 1973) and due to its acid nature may have problems related to Mn excess.

Instituto Agronômico do Paraná (IAPAR), Rodovia do Café, BR 376, Km 496, CP 129, 84001-970, Ponta Grossa, PR, Brasil, Email: lzanao@iapar.br. *Autor para correspondência.

"Universidade Federal de Viçosa (UFV), Viçosa, MG, Brasil.

"'Universidade Federal de Uberlândia (UFU), Uberlândia, MG, Brasil. 
For Si accumulating plants such as rice and most of the Gramineae, in soils like those in the Cerrado region, it is expected a positive response to the application of $\mathrm{Si}$. This study aimed the evaluation of the effects of $\mathrm{Si}$ and $\mathrm{Mn}$ fertilization on the production of biomass, plant architecture and $\mathrm{Si}$ and $\mathrm{Mn}$ uptake in rice plants cultivated in a manganese enriched Acrustox in greenhouse conditions.

The treatments were arranged in a $2 \times 5$ factorial with two doses of $\operatorname{Si}\left(0\right.$ and $\left.1000 \mathrm{mg} \mathrm{dm}^{-3}\right)$, five doses of $\mathrm{Mn}\left(0,4,12,16\right.$ and $\left.20 \mathrm{mg} \mathrm{dm}^{-3}\right)$ and four replications, in a randomized block design. The experimental unit consisted of a $2.5 \mathrm{dm}^{3}$ pot containing $2.0 \mathrm{dm}^{3}$ of soil with six rice plants. The Acrustox used for plant growth was collected in the city of Três Marias, Minas Gerais State, Brazil, and presented a $\mathrm{Si}$ availability $\left(\mathrm{CaCl}_{2} 0.05 \mathrm{~mol} \mathrm{~L}^{-1}\right.$ extraction) equal to $1.2 \mathrm{mg}$ $\mathrm{dm}^{-3}$ (Si-deficient soil) and a Mn availability (Mehlich1 extraction) equal to $5 \mathrm{mg} \mathrm{dm}^{-3} \mathrm{Mn}$. The soil chemical and physical characteristics are: $180 \mathrm{~g} \mathrm{~kg}^{-1}$ clay, $\mathrm{pH}$ in water $4.90,0.3 \mathrm{mg} \mathrm{dm}^{-3} \mathrm{P}$ (Mehlich-1 extraction), $6.0 \mathrm{mg}$ $\mathrm{dm}^{-3} \mathrm{~K}$ (Mehlich-1 extraction), $0.25 \mathrm{cmol}_{\mathrm{c}} \mathrm{dm}^{-3} \mathrm{Al}^{3+}$, $0.07 \mathrm{cmol}_{\mathrm{c}} \mathrm{dm}^{-3} \mathrm{Ca}^{2+}, 0.01 \mathrm{cmol}_{\mathrm{c}} \mathrm{dm}^{-3} \mathrm{Mg}^{2+}, 3.0 \mathrm{cmol}_{\mathrm{c}} \mathrm{dm}^{-3}$ $\mathrm{H}+\mathrm{Al}, 2.3 \% \mathrm{~V}, 9 \mathrm{~g} \mathrm{~kg}^{-1}$ organic matter, $0.32 \mathrm{mg} \mathrm{dm}^{-3} \mathrm{~B}$, $0.06 \mathrm{mg} \mathrm{dm}^{-3} \mathrm{Cu}, 33.5 \mathrm{mg} \mathrm{dm}^{-3} \mathrm{Fe}, 0.135 \mathrm{~kg} \mathrm{~kg}^{-1}$ field capacity and $1.02 \mathrm{~kg} \mathrm{dm}^{-3}$ density.

The soil for the treatments with zero Si had the $\mathrm{pH}$ corrected with $\mathrm{CaCO}_{3}$ and for the treatments with $1000 \mathrm{mg} \mathrm{dm}^{-3} \mathrm{Si}$ it was used wollastonite, a calcium silicate with $20.7 \% \mathrm{Si}$ and $42.4 \% \mathrm{CaO}$, which acts as a corrective of soil acidity. The quantity of $\mathrm{CaCO}_{3}$ was calculated to balance the quantity of $\mathrm{Ca}$ supplied by the wollastonite and $0.20 \mathrm{~g} \mathrm{dm}^{-3} \mathrm{MgCO}_{3}$ was applied for all treatments. The mixture of soil+corrective material was incubated, keeping the moisture at $80 \%$ field capacity for 30 days. After incubation, $400 \mathrm{mg} \mathrm{dm}^{-3}$ of $\mathrm{P}$ $\left(\mathrm{CaHPO}_{4}\right)$ and $\mathrm{Mn}\left(\mathrm{MnCl}_{2} \cdot 4 \mathrm{H}_{2} \mathrm{O}\right)$ doses $(0,4,12,16$ and $20 \mathrm{mg} \mathrm{dm}^{-3}$ ) were added and incorporated. Three days after incubation, soil samples of $0.2 \mathrm{dm}^{3}$ were removed from each experimental unit and Si content was determined (KORNDÖRFER et al., 2004). From these samples, the $\mathrm{pH}$ in water $(1: 2.5$, soil water ratio) and the soil Ca were determined (EMBRAPA, 1997) in two composite samples, one from the treatments limed with calcium carbonate $\left(\mathrm{CaCO}_{3}\right)$ and the other from the treatments limed with wollastonite $\left(\mathrm{CaSiO}_{3}\right)$.

Rice (15 seeds of the variety Metica-1 per pot) was seeded at a depth of $1 \mathrm{~cm}$ and the first thinning was performed five days after emergence (DAE), leaving 10 plants per pot, and adding the first application of $\mathrm{N}$ and micronutrients, and the sole application of $\mathrm{K}$ and $\mathrm{S}$. The second thinning was performed at 10DAE, leaving six plants per pot, and adding the second (15DAE) and third (30DAE) nitrogen and micronutrient applications. The nutrients were added through nutrient solutions $\left(25 \mathrm{~mL} \mathrm{dm}^{-3}\right.$ for each application) (ZANÃO JÚNIOR et al., 2009).

At 45DAE the leaf insertion angles of the $7^{\text {th }}$ and $8^{\text {th }}$ leaves of each plant (counting from the first completely expanded leaf from bottom to top) were measured (with a compass and protractor). The plants were collected, washed in deionized water and dried in forced air circulation oven at $65^{\circ} \mathrm{C}$ for $72 \mathrm{~h}$. It was recorded the dry matter weight, the leaves were ground (Wiley, $0.84 \mathrm{~mm}$ screen) and the dry matter mineralized (nitric and perchloric acid extracts). It was determined the $\mathrm{K}$ content by flame spectrophotometer, the $\mathrm{Mn}$ content by atomic absorption spectrophotometry and the Si content (alkaline digestion extracts) by a colorimetric method (KORNDÖRFER et al., 2004).

The statistical analysis included the analysis of variance (ANOVA), and the analysis of the Si x Mn interaction for the evaluation of the polynomial effects of Mn, with and without the application of Si by the Ftest $(\mathrm{P}<0.05)$. Afterwards, regression equations (linear and quadratic models) for the variables under evaluation were adjusted as a function of doses of $\mathrm{Mn}$, with or without the addition of Si to the soil.

Besides correcting soil acidity, wollastonite increased the content of available $\mathrm{Si}$ in the soil which resulted in greater Si leaf content in the plants (Table 1). Greater shoot dry matter production and smaller leaf insertion angle were observed in the plants with the application of $1000 \mathrm{mg} \mathrm{dm}^{-3}$ of $\mathrm{Si}$ in the soil as compared to the plants without Si application (Table 1). Likewise, the application of $1000 \mathrm{mg} \mathrm{dm}^{-3}$ of Si in the soil resulted in greater $\mathrm{Si}$ content and lesser Mn content in the leaves as compared to treatment without $\mathrm{Si}$ (Table 1). A greater Si content was found in the soil that received $1000 \mathrm{mg} \mathrm{dm}^{-3} \mathrm{Si}$ reflecting the action of the wollastonite adding $\mathrm{Si}$ to the soil (Table 1). It has been reported an increase in the biomass production of rice cultivated with the addition of Si (PEREIRA et al., 2007; ZANÃO JÚNIOR et al., 2009).

The plants grown in soil that received $1000 \mathrm{mg} \mathrm{dm}^{-3} \mathrm{Si}$ produced more dry matter than those with no Si addition, and presented leaves more erect as a result of the smaller leaf insertion angle (Table 1) showing a more adequate architecture for plant growth. More erect leaves allow the plants to exploit a greater available space, intercepting more photosynthetically 
Table 1 - Values of $\mathrm{pH}$ in water, $\mathrm{Ca}, \mathrm{Si}$ and Mn content in the soil, shoot dry matter (DMshoots), leaf insertion angle (LIA) and Si and Mn content in leaves and roots of rice plants cultivated in a soil that received two doses of $\mathrm{Si}$ and five doses of Mn. .

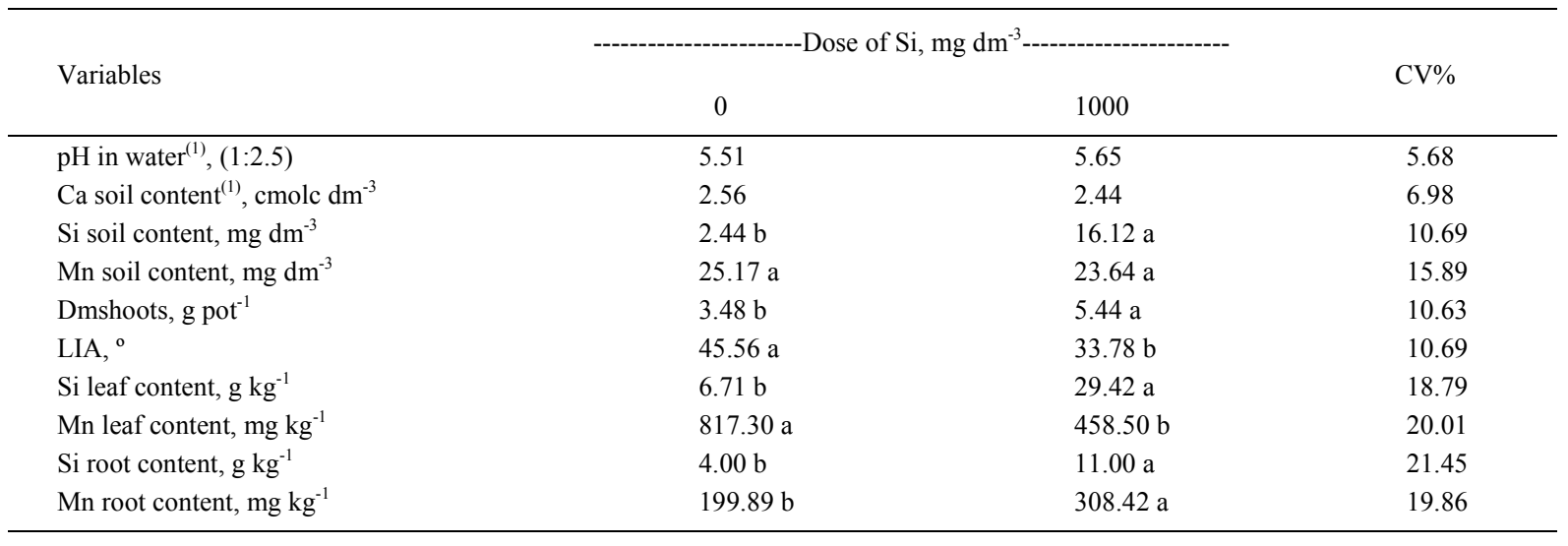

(1) Data obtained from compound sample.

Averages followed by distinct letters in the column differ significantly among each other by Tukey's Test (P $\leq 0.05)$.

active radiation and converting a greater quantity of photoassimilates into dry matter (ZANÃO JÚNIOR et al., 2010).

There was no significant difference between the soil Mn content, with and without Si addition, which is due to the similar values of $\mathrm{pH}$ at the zero and the $1000 \mathrm{mg} \mathrm{dm}^{-3}$ Si treatments (Table 1). OLIVEIRAJÚNIOR et al. (2000), working with soybean cultivated in a cerrado soil, reported that soil $\mathrm{pH}$ is the most important factor in controlling the availability of Mn for plants.

Although the addition of Si to soil had no effect in the soil Mn availability (Table 1), it lowered the $\mathrm{Mn}$ content in the leaves and increased it in the roots (Table 1). This effect of $\mathrm{Si}$ in the plant $\mathrm{Mn}$ is helpful for the plant and is reported in studies showing the benefits of Si reducing the Mn toxicity in crops (LIANG et al., 2007), as it was found in the present study. The ratio MnRoots/MnLeaves was $4 / 1$ in the soil without $\mathrm{Si}$ application, and 1.48/1 in the soil with $\mathrm{Si}$ application (Table 1). The simultaneous lowering of the $\mathrm{Mn}$ in the shoots with an increase in the roots (Table 1) in the supplied Si soil shows a blocking of the Mn movement from roots to shoots, allowing a more homogeneous distribution of $\mathrm{Mn}$ between those plant parts.

Without Si application, there was a significant response (quadratic model) for the production of rice shoot dry matter (DM) as a function of the increase of soil applied with Mn (Figure 1). The increase in DM was observed until the Mn dose reached about $12 \mathrm{mg} \mathrm{dm}^{-3}$ and declined above this point. For the treatments with addition of $1000 \mathrm{mg} \mathrm{dm}^{-3} \mathrm{Si}$, there was no response in the DM as a function of the increase in the Mn dose applied to soil (Figure 1). Deficiency of $\mathrm{Mn}$ negatively affects productivity (LIDON \& TEIXEIRA, 2000) since it is an essential element and participates in diverse biochemical reactions in the plant such as plant photosynthesis. Nevertheless, in the present study, visual symptoms of Mn deficiency in plants were not detected, even in treatments with no addition of $\mathrm{Mn}$. The lack of plant response to soil added $\mathrm{Mn}$ in the $+\mathrm{Si}$ soil, and the greater shoot DM in these plants compared to that in -Si soil (Figure 1) suggest that, even at the low Mn doses, the photosynthesis was kept efficient in the $+\mathrm{Si}$ soil. As the Mn doses increased, although visual Mn toxicity symptoms were not detected in the -Si soil, the harmful symptom was the loss in DM at doses around $12 \mathrm{mg}$ $\mathrm{dm}^{-3} \mathrm{Mn}$ and above (Figure 1).

The Mn content in the soil increased (quadratic model) as a function of the Mn doses applied, with and without the addition of $\mathrm{Si}$ (Figure 1). The result was an increase $\mathrm{Mn}$ availability to plants which allowed a greater plant uptake and a higher Mn content in leaves and roots, as found by PEREIRA et al. (2001) in rice plants supplied with $\mathrm{Mn}$ in greenhouse. In the plant, the Mn content in the leaves increased linearly in the -Si soil, and quadratically, with more discrete increments in the $+\mathrm{Si}$ soil, as a function of Mn dose raising (Figure 1).

In both $\mathrm{Si}$ treatments $\left(0\right.$ and $\left.1000 \mathrm{mg} \mathrm{dm}^{-3}\right)$, the $\mathrm{Si}$ content in the soil, plants roots and plant leaves, and the leaf insertion angle, did not respond to the increase of Mn in the soil (Figure 1) showing that Mn 

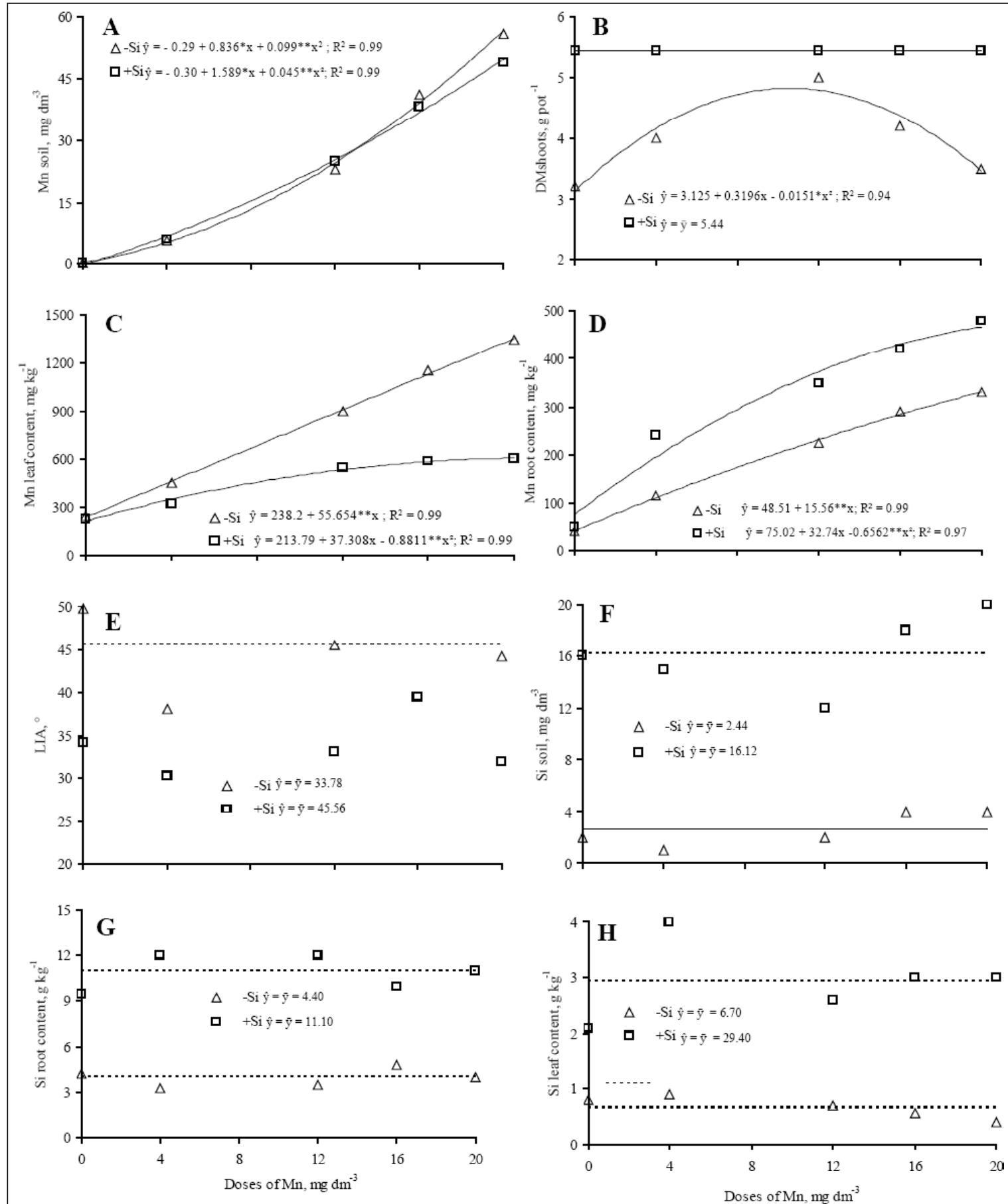

Figure 1 - Mn content in the soil (A), shoot dry matter production (B) Mn content in leaves (C), Mn content in roots (D), leaf insertion angle (E), Si content in the soil $(\mathrm{F})$ and $\mathrm{Si}$ content in roots $(\mathrm{G})$ and leaves $(\mathrm{H})$ of rice plants cultivated in a soil that received two doses of $\mathrm{Si}$ and five doses of $\mathrm{Mn}$.

does not influence the role of $\mathrm{Si}$ in the rice plant nutrition.

Application of Si to the soil increases shoot dry matter production of rice plants.

Above $12 \mathrm{mg} \mathrm{dm}^{-3} \mathrm{Mn}$ it was detected, $\mathrm{Mn}$ toxicity whit reduction of shoot dry matter production and the application of $1000 \mathrm{mg} \mathrm{dm}^{3} \mathrm{Si}$ to the soil alleviates this detrimental effect.

Si reduces the transport of $\mathrm{Mn}$ from roots to shoots, balancing the Mn distribution between roots and shoots, and reducing the effects of Mn toxicity. 


\section{AGRADECIMENTOS}

The authors Fontes and Korndörfer thank the National Council of Scientific and technological Development $(\mathrm{CNPq})$ for the research fellowship. Zanão Júnior was supported by the Fundação de Amparo à Pesquisa do Estado de Minas Gerais (FAPEMIG) and CNPq.

\section{REFERENCES}

EL-JAOUAL, T.; COX, D.A. Manganese toxicity in plants. Journal of Plant Nutrition, New York, v.21, p.353-386, 1998. Available from: <http://www.informaworld.com/smpp/ content $\sim \mathrm{db}=$ all? content $=10.1080 / 01904169809365409>$. Accessed: Nov. 20, 2009. doi: 10.1080/019041698093 65409.

EMPRESA BRASILEIRA DE PESQUISA AGROPECUÁRIA EMBRAPA. Manual de métodos de análise de solo. 2.ed. Rio de Janeiro: Centro Nacional de Pesquisa de Solos, 1997. $212 \mathrm{p}$.

KORNDÖRFER, G.H. et al. Análise de silício: solo, planta e fertilizante. Uberlândia: GPSi-ICIAG-UFU, 2004. 34p. (Boletim técnico, 2).

LIANG, Y. et al. Mechanisms of silicon-mediated alleviation of abiotic stresses in higher plants: a review. Environmental Pollution, Barking, v.147, p.422-428, 2007. Available from: $<$ http:/ /www.sciencedirect.com/science?_ob=ArticleURL\&_udi=B6VB5-

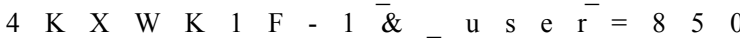
$9367 \&$ cover Date=05\%2F $31 \% 2$ F 2007 \& 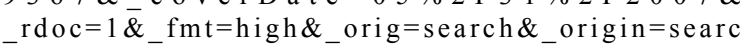 h \&_s ort $=$ d \&_d o c a n c hor $=\&$ vi e w $=$ c \&_a c

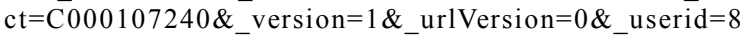
509367\&md5=d3915a6b392625f31 ccc55a6d8be6213\&searchtype $=\mathrm{a}>$. Accessed: Oct. 21, 2009. doi:10.1016/ j.envpol.2006.06.

LIDON, F.C.; TEIXEIRA, M.G. Rice tolerance to excess Mn: implications in the chloroplast lamellae and synthesis of a novel Mn protein. Plant Physiology and Biochemistry, Paris, v.38, p.969-978, 2000. Available from: <http://www.sciencedirect.com/
science?_ob=MImg\&_imagekey=B6VRD-41Y85M9-8F \& c d i $=6232 \&$ u s e r $=8509367 \&$ p i i $=S$ $0981942800012079 \&$ origin $=$ search\&_coverDate $=12 \%$ $2 \mathrm{~F} 31 \% 2 \mathrm{~F} 2000 \&$ sk $=999619987 \& v i \mathrm{w}=\mathrm{c} \& \mathrm{wchp}=\mathrm{dGLzVzb}-$ zSkWA\&md5 $=3 \mathrm{c} 4 \mathrm{cc} 2 \mathrm{e} 8 \mathrm{~b} 21 \mathrm{be} 039353220 \mathrm{a} 5 \mathrm{c} 3 \mathrm{a} 92634 \& \mathrm{ie}=/$ sdarticle.pdf $>$. Accessed: Oct. 01, 2009. doi:10.1016/S09819428(00)01207-9.

OLIVEIRA JUNIOR, J.A. et al. Efeitos do manganês sobre a soja cultivada em solo de Cerrado do Triângulo Mineiro. Pesquisa Agropecuária Brasileira, Brasília, v.35, p.16291636, 2000. Available from: <http://www.scielo.br/ scielo.php?script $=$ sci_arttext\&pid $=$ S0 100-204X20000008 $00016 \& \operatorname{lng}=$ en $\& n r m=$ iso $>$. Accessed: Oct. 10, 2009. doi: 10.1590/S0100-204X2000000800016.

PEREIRA, G.D. et al. Doses e modos de adubação com manganês e seus efeitos na produção da cultura do arroz. Revista Brasileira de Ciência do Solo, Viçosa, v.25, p.625-633, 2001.

PEREIRA, H.S. et al. Avaliação de fontes e de extratores de silício no solo. Pesquisa Agropecuária Brasileira, Brasília, v.42, p.239-247, 2007. Available from: $<$ http://www.scielo.br/ scielo.php?script=sci_arttext \& pid=S $0100-$ 204X2007000200013\&lng=pt\&nrm=iso $>$. Accessed: Oct. 15, 2009. doi: 10.1590/S0100-204X2007000200013.

RAIJ, B. van.; CAMARGO, O.A. Sílica solúvel em solos. Bragantia, Campinas, v.32, p.223-236, 1973.

ZANÃO JÚNIOR, L.A. et al. Arroz cultivado em solução nutritiva com doses de manganês e silício. Revista Brasileira de Ciência do Solo, Viçosa, v.34, p.1629-1639, 2010.

ZANÃO JÚNIOR, L.A. et al. Aplicação do silício para aumentar a resistência do arroz à mancha-parda. Pesquisa Agropecuária Brasileira, Brasília, v.44, p.203-206, 2009. Available from: $<$ http://www.scielo.br/scielo.php?script=sci_arttext\&pid=S0100204X2009000200013\&lng=pt\&nr m=iso $>$. Accessed: Oct. 15, 2009. doi: 10.1590/S0100-204X2009000200013. 